УДК 37.014.5(4)(477)"1991/2018"

О. І. Якимчук, к. фрілос. н.

\title{
ЄВРОПЕЙСЬКИЙ ВЕКТОР РОЗВИТКУ УКРАЇНСЬКОЇ ОСВІТИ В ПЕРІОД УТВЕРДЖЕННЯ НЕЗАЛЕЖНОСТІ
}

Актуальність теми дослідження. Пострадянський етап українського державотворення позначився кардинальними рефоормами в різних сфрерах соціальної життєдіяльності, в тому числі і в освітній. Очевидною альтернативою колишнім радянським стандартам і обмеженням стала європейська перспектива.

Постановка проблеми. Автор звертає увагу на кардинальні зміни освіти України, які відбулися у змісті та формі й вимагають подальшого вдосконалення та переосмислення, а також у освітньому просторі нашої сучасної держави залишаються не вирішеними ряд проблем, що пов'язані з європейськими стандартами освітньої діяльності, без урахування національних педагогічних особливостей.

Аналіз останніх досліджень і публікацій. Трансформацію української освіти в контексті розвитку світових інформаційних технологій досліджують Н. Білоцерківська, О. Говоровська, І. Єлдинова, Т. Жихарєва, О. Комаровський, В. Мозальов, Н. Скотна, О. Чернявська, О. Якименко та інші.

Виділення недосліджених частин загальної проблеми. Некритичне сприйняття західних стандартів призводить до виникнення багатьох суперечностей, важливо звернути увагу на співвідношення впливу західних освітніх моделей і застосування вітчизняних досяанень у освіті.

Постановка завдання. Акцентується увага на критичному аналізі проектів, які мають пройти реформування національної системи освіти, з'ясовуються особливості, можливості та доцільність реалізації європейських стандартів в освіті.

Виклад основного матеріалу. Розглядається діяльність міжнародних та зарубіжних фоондів, певні положення, які співвідносяться з європейськими стандартами освіти, рефоорматорські задуми щодо освітньої сфери та можливості їх фрінансування.

Висновки. Варто здійснювати моніторинг фрункціонування системи національної освіти та виробити його універсальну систему за певними параметрами.

Ключові слова: людина, освіта; культура; європейські стандарти освіти; рефоорма національної системи освіти; суперечності розвитку освіти; міжнародні освітні фронди.

O. I. Yakymchuk, Candidate of Philosophical Sciences

\section{EUROPEAN VECTOR OF UKRAINIAN EDUCATION DEVELOPMENT DURING APPROVAL OF INDEPENDENCE}

Urgency of the research. The post-Soviet stage of Ukrainian statehood was marked by radical reforms in various spheres of social life, including the educational sphere. An obvious alternative to the former Soviet standards and restrictions is the European perspective.

Target setting. The author draws attention to the fundamental changes in the education of Ukraine, which took place in its content and form, and require further improvement and rethinking. Also in the educational space of our modern state, a number of problems related to European standards of educational activity remain unresolved, without taking into account national pedagogical features.

Actual scientific researches and issues analysis. The transformation of Ukrainian education in the context of the development of world information technologies is studied by N. Bilotserkivska, O. Hovorovska, I. Yeldynova, T. Zhykharieva, O. Komarovskyi, V. Mozalov, N. Skotna, O. Cherniavska, O. Yakymenko et al.

Uninvestigated parts of general matters defining. Uncritical perception of Western standards leads to many contradictions, it is important to pay attention to the relationship between the influence of Western educational models and the application of domestic achievements in education. 
The research objective. Attention is drawn to the critical analysis of projects to be reformed by the national education system, the peculiarities, possibilities and feasibility of the implementation of European standards in education are clarified.

The statement of basic materials. The article deals with the activities of international and foreign funds, certain provisions that are in line with European standards of education, reform ideas for the educational sphere and the possibility of their financing.

Conclusions. It is necessary to monitor the functioning of the national education system and develop its universal system according to certain parameters.

Keywords: person; education; culture; European standards of education; reform of the national education system; contradictions in the development of education; international educational funds.

DOI: 10.25140/2412-1185-2018-2(12)-88-95

Актуальність теми дослідження. На сьогоднішній день відбулися кардинальні зміни у формі й змісті освіти в Україні, які вимагають подальшого переосмислення та вдосконалення. Відповідно лишаються не вирішеними певні проблеми у освітньому просторі нашої держави, які зокрема пов' язані з надмірним захопленням європейськими стандартами освітньої діяльності.

Постановка проблеми. Некритична орієнтація на європейські стандарти в освіті може суперечити національним особливостям та традиціям в цій сфері. Непідготовленість національного освітнього простору до впровадження європейських стандартів, ідеалізація європейської моделі в цій сфрері без належної адаптації до вітчизняних умов безумовно шкодить прогресу освітньої реформи в Україні.

Аналіз останніх досліджень і публікацій. Трансформаційні процеси в організації української освіти активно обговорюються та досліджуються науковцями. Н. Скотна розглядає сутність глобалізації та її вплив на розвиток вищої освіти в Україні. Зміст і особливості трансформації вищої освіти в Україні аналізують О. Говоровська та О. Якименко. В. Мозальов досліджує вітчизняний та зарубіжний досвід моніторингу якості освіти. Діяльність міжнародних та зарубіжних фондів в освітянській галузі вивчають І. Єлдинова, Т. Жихарєва, О. Чернявська, О. Комаровський та інші. Н. Білоцерківська наголошує, що така робота впливає на політичну складову соціокультурної компетентності молоді в умовах сучасного суспільства.

Виділення недосліджених частин загальної проблеми. Необхідно проаналізувати співвідношення впливу західних освітніх моделей і застосування вітчизняних досягнень у освіті.

Постановка завдання. Європейський вектор розвитку української освіти в період утвердження незалежності

Виклад основного матеріалу. В цьому контексті розглянемо діяльність Міжнародного фонду "Відродження" та програму Дж. Сороса. Як відомо місія Міжнародного фонду "Відродження" - фінансово й організаційно сприяти становленню відкритого, демократичного суспільства в Україні шляхом підтримки значущих для його розвитку громадських ініціатив. За ініціативи Міжнародного фонду "Відродження" здійснюються гранти, орієнтовані на учнівську молодь, метою яких, наприклад, $є$ залучення творчих дітей до розвитку волонтерського руху через діяльність шкільних євро клубів України та Польщі [11] і платфрорми молодіжної мобільності й обміну з Україною. Тому завдяки такому партнерству українські школярі зможуть не тільки брати участь у таких програмах, як "Comenius" та "Leonardo da Vinci", а й стане можливою реалізація окремих проектів на кшталт:

1) проведення літнього табору для українських і польських лідерів шкільних євроклубів;

2) обміни учнями й учителями між школами Польщі та України;

3) створення карти активних проектів;

4) запровадження моделі волонтерів за прикладом польського досвіду “чудових вісімок" у Стрийському районі [13].

Разом з тим вітчизняні науковці цілком справедливо ставлять питання про недоліки у діяльності Міжнародного фонду "Відродження" та програми Дж. Сороса щодо побудови "відкритого суспільства, в якому освіта відіграє одну з основних ролей.

Зокрема, фахівці застерігають, що питання інтеграції України в європейський освітній простір у рамках Болонської декларації акцентувало увагу на небезпеці сліпого копіювання інноваційних 
процесів в освіті. Застереження зводяться до упередження механічного копіювання реформи замість того, щоб приділяти головну увагу умовам, у яких можливий їі успіх [16, с. 43-44].

Вочевидь, європейські стандарти з одного боку вимагають відкритості та мобільності у взаємодії освітніх просторів різних країн, а з другого боку це сприяє "вимиванню інтелектуальних ресурсів з менш розвинених у соціально-економічному плані країн до більш розвинених. 3 цього приводу Н. Скотна зазначає, що особливу загрозу для національних систем вищої освіти становить поява так званих освітніх провайдерів. В економічно слаборозвинених країнах ця тенденція збільшує "відтік інтелекту" за кордон. Найталановитіша молодь може бути селекціонована ще в період навчання, з наступним запрошенням продовжити освіту в країні походження провайдера. У результаті потоки імміграції здібної молоді збільшуватимуться. Потенціал освітніх провайдерів зростає в міру глобалізації, яка об'єктивно прискорюється діями Європейського центру з питань вищої освіти ЮНЕСКО, Ради Європи, Європейської комісії та інших міжнародних європейських організацій. Яскравим свідченням цього є Болонський процес. Тож, на думку цієї дослідниці, усім країнам (його учасницям) треба ще раз серйозно задуматися про можливості розширення експорту освітніх послуг, зокрема й за допомогою освітніх провайдерів, про співвідношення традиційних і нетрадиційних форм освіти, конкурентоспроможність національної освіти. Можна стверджувати, що культурна глобалізація вищої освіти $є$ нерівномірним, суперечливим і складним явищем. Для країн, що не вписуються в цю модель, зокрема й для України, культурна глобалізація вищої школи матиме, ймовірно, такі наслідки:

популяризація глобальних мультикультурних цінностей;

посилення світового домінування євроатлантичної культури;

поява зарубіжних освітніх провайдерів на територіях національних держав;

втрата національної культури та ідентичності [12, с. 80-81].

Виходячи з вищенаведеного варто критично проаналізувати різноманітні проекти реформування національної системи освіти, чітко з'ясувати особливості, можливості та навіть доцільність реалізації певних європейських стандартів в цій сфрері.

На сьогоднішній день, в державі завершується обговорення проекту Концепції розвитку освіти України до 2025 рр., яку розробила Стратегічна дорадча група «Освіта» (керівник Г. Касьянов), створена в рамках спільного проекту Міжнародного фонду «Відродження» та Благодійного фонду «Інститут розвитку освіти» для надання консультативної й експертної підтримки МОН України в розробці Дорожньої карти освітньої реформи. Концепція включає п'ять основних напрямів розвитку освітньої галузі, реформування яких здійснюватиметься впродовж наступних років. Передусім у структурі середньої освіти запропоновано:

- повернутися до 12-річного навчання в школі та узгодити з типовими європейськими нормами загальну тривалість навчального року;

- застосувати ЗНО при переході на різні рівні навчання у школі (з I на II ступінь рейтинг враховується лише для моніторингу якості освіти, з II на III ступінь - для диференціації подальшої освітньої траєкторії: професійна школа, ліцей, гімназія та інші типи ЗНЗ (підготовка до вищої освіти);

- передбачити з 2017 року повний перехід старшої школи на профільну підготовку та створити навчальні заклади нових типів (III ступеня);

- забезпечити здобуття освіти I ступеня за місцем проживання, використовуючи різні фоорми навчання (сімейне, індивідуальне тощо);

- запровадити 32018 року обов'язкову національну багаторівневу сертифікацію випускників старшої школи й закладів професійної освіти з іноземних мов та комп'ютерних технологій;

- забезпечити рівний доступ до освіти шляхом легалізації й спрощення процедури сімейного, індивідуального, екстернатного навчання, консолідації мережі шкіл;

- перейти на систему відбору/замовлення підручників, навчальних посібників та інших навчальних засобів безпосередньо школами, скасувати конкурси навчальної літератури;

- змінити систему оплати праці вчителів і керівників шкіл, відмовившись від поурочної оплати, та перейти на оплату повного робочого дня педагогічного працівника тощо [14].

Вищеозначені положення реформування середньої освіти, які співвідносяться з європейськими стандартами, ввійшли у законопроект, що обговорюється в українському парламенті. Разом з тим, деякі з цих положень критично сприймаються науковими й громадськими колами. Так, противники 12-річного навчання в школі акцентують увагу на запізнілому соціальному старті молодих людей та низької середньої тривалості життя в Україні як аргументах проти зміни термінів навчання. 
Варто зазначити, що низка реформаторських задумів щодо освітньої сфрери в Україні за європейськими стандартами стикається з недостатнім фінансуванням цієї галузі з боку держави. Відповідно у Європі, застосовуючи різноманітні моделі фрінансування освітня сфера динамічно розвивається. Саме тому необхідно наповнити прагнення до європейських стандартів у вітчизняній освіті належною економічною підтримкою. Держава має чітко визначати об'єми замовлення за різними спеціальностями, виходячи з соціально-економічних потреб нашої держави.

Для того, щоб зрозуміти наскільки європейські освітні стандарти реалізувалися в Україні та окреслити напрямки зняття протиріч щодо їх імплементації в нашій державі варто постійно здійснювати моніторинг функціонування системи національної освіти. Як відомо самі технології моніторингу знань студентів (учнів) розроблялися як у вітчизняний педагогічній науці, так і були запозичені за кордоном. На нашу думку, існує необхідність вироблення універсальної системи моніторингу національної системи освіти за різноманітними параметрами. В той же час не варто ідеалізувати зарубіжні, зокрема європейські, моніторингові технології в освіті, які були створені 3 урахуванням потреб та особливостей конкретної країни.

Зважаючи на певні здобутки, проблема оцінювання та моніторингу якості вищої освіти залишається актуальним напрямком удосконалення управління національною системою освіти. Адже без збору об'єктивної інформації про стан системи, її аналізу та оцінки, їх обговорення із зацікавленими групами, неможливе прийняття адекватних управлінських рішень на різних шаблях управління освітою. Оскільки в Україні регіональні і національна системи оцінювання й моніторингу якості освіти знаходяться на етапі становлення, а існуючі державні освітні стандарти потребують перегляду, доопрацювання й оновлення, виникає необхідність та актуальність у вивченні досвіду тих країн, де система моніторингу знаходиться на високому рівні, а освітні стандарти є ефективними, дієвими й обґрунтованими [8, с. 101-102].

Таким чином, проаналізовані вище суперечливі орієнтації на європейські стандарти в процесі розбудови національної системи освіти не знімають з порядку денного значущість та незворотність європейського вектору розвитку вітчизняного освітнього простору. В той же час неприпустимим $є$ некритичне копіювання закордонних освітніх норм та технологій без урахування національних педагогічних традицій.

На наше переконання, важливу роль у розвитку освітньо-наукового простору нашої країни відіграє не тільки держава, а й діяльність зарубіжних фондів, як структур громадянського суспільства. За даними Національної академії педагогічних наук України в нашій державі здійснює діяльність понад 30-ти зарубіжних фондів, які прямо чи опосередковано сприяють розвитку освіти. До таких структур відносять: Міжнародний Вишеградський Фонд (The International Visegrad Fund - IVF), Фонд цивільних досліджень і розвитку США (ФЦДР), Фонд Арістотеля Онассіса (Програма дослідницьких грантів та стипендій для іноземних дослідників, викладачів та аспірантів), Фонд Альфреда Слоуна заснований у США у 1934 році генеральним директором «Дженерал Моторз» А. Слоуном, Фонд «Євразія» (агентство США по міжнародному розвитку), Фонд Форда Ford Foundation, Бельгійський національний фонд сприяння науковим дослідженням Belgian National Fund for Scientific Research, European Science Foundation, Фонд «Ноу-Хау» (Британська урядова програма технічного співробітництва з країнами Центральної і Східної Європи. Основне завдання фонду - підтримка країн вказаного регіону на шляху до ринкової економіки і плюралістичної демократії, Європейський науковий фонд (Асоціація з 68 організацій, що займаються науково-організаційно діяльністю у 24 країнах Європи. Координує загальноєвропейські наукові ініціативи з метою підтримки наукових досліджень високого рівня), Стипендіальний фонд Музею історії Польщі, Посольський фонд США Програма «Збереження культурних цінностей», Фонд Освіта для Демократії - Education for Democracy Foundation, Warsaw Фонд Чарльза Стюарта Мотта, Міжнародний Фонд "Відродження", Фонд Ганнса Зайделя, Фонд Конрада Аденауера, Фонд ім. Фрідріха Еберта, Фонд Олександра фон Гумбольдта та ін. [9]

Зокрема, з 1992 року Фонд Ганнса Зайделя відкрив своє постійне представництво (проектне бюро в Україні - третє у країнах Східної Європи після Будапешта та Праги) у Києві. Метою його діяльності у нашій країні стала підтримка реформ і процесів демократичного розвитку, налагодження політичної освіти дорослого населення шляхом організації багатосторонніх зустрічей, семінарів, практикумів і конференцій із політичної або державної і конституційно-правової тематики, консультацій у законодавчій галузі тощо. Цей фонд пропонує різноманітні освітні заходи, 
надає кожен рік кандидатам та докторам наук декілька стипендій для дослідницької роботи у німецьких університетах [10].

З 1994 р. в Україні працює Фонд Конрада Аденауера, який реалізує цілу низку проектів в тому числі й освітнього характеру. Зокрема дана організація реалізовувала «Програму-діалог 3 політичної освіти молодих політиків». Для реалізації цієї ідеї регулярно проводилися семінари за такими темам: правова держава; виборчі системи і політичні партії; екологія; жінки в професії і політиці; європейська інтеграція; підприємництво; національні меншини; права людини [3, с. 14].

У 2014 році Інститутом громадянської освіти за підтримки Представництва Фонду Конрада Аденауера в Україні була розроблена Концепція політичної освіти в Україні, в якій визначалися їі концептуальні засади та основні завдання щодо підвищення громадянської компетентності молоді та побудови демократичного європейського суспільства [1, с. 10].

Фонд Конрада Аденауера також реалізував в Україні «Програму з розвитку демократичних 3Мl». Наголос в ній робився на професійній підготовці журналістів, на питаннях журналістської етики і права в інформаційній сфері. 3 цієї тематики Представництво Фонду проводило зустрічі 3 журналістами, семінари для регіональних журналістів, організовувало інформаційні програми в Німеччині [6, с. 40].

У 1993 році в Україні почав працювати Фонд ім. Фрідріха Еберта. Фонд сприяє здійсненню дослідницьких проектів з питань соціальної історії, економічної політики, трудових і соціальних відносин, організовує просвітницькі заходи - конференції, семінари, "круглі столи”, надає стипендії для студентів та молодих випускників в усіх дисциплінах. Бібліотека Фонду ім. Фрідріха Еберта налічує більше 650000 томів, а в архіві Фонду - найбільше зібрання документів з історії європейського робітничого руху [4, с. 10].

Широку освітню діяльність у різних країнах світу, в Україні зокрема, здійснює й Фонд Олександра фон Гумбольдта. Важливо, що даний фонд має широку програму продовження співпраці 3 колишніми стипендіатами, яка включає в себе поряд з іншим надання їм субсидій для придбання наукового обладнання та наукової літератури, нові короткострокові запрошення та фрінансування їх участі у роботі конгресів, проведених у Федеративній Республіці Німеччина. Варто підкреслити, що стипендії надаються для навчання у ВНЗ, підвищення кваліфікації, ознайомчих поїздок, участі в конгресах. Крім того, існує така форма надання фінансованої підтримки для проведення дослідження, як підтримка Фондом Гумбольдта дослідницьких груп. В рамках цієї програми Фонда Гумбольдта є можливість формувати зв'язок між Українськими установами, в яких працюють колишні стипендіати Фонду, з науковими установами та університетами Німеччини. Метою цієї програми є створення сприятливого базису для розвитку довгострокової інтернаціональної кооперації між науковими установами України та Німеччини. На такі проекти спільної праці між науковими групами може бути виділено до 55000 євро на період до 3-х років. Ці кошти можуть бути використані на фінансування наукових візитів з обох сторін (української та німецької) тривалістю до 3-х місяців, проведення конференцій. Також передбачена часткова витрата цих коштів на видавничу діяльність, устаткування тощо [5, с. 236-237].

Значущими в плані розвитку та налагодження освітньої системи нашої країни у відповідності до вимог Болонського процесу, є програми міжнародного Вишеградського Фонду. Даний фонд $є$ міжнародною організацією, заснованою 9 червня 2000 р., у м. Братислава. Його засновниками $\epsilon$ уряди країн Вишеградської групи (V4) - Чехія, Угорщина, Польща і Словаччина. Вишеградський фонд співпрацює з країнами Східної Європи через здійснення чотирьох грантових програм та декількох університетських програм, спрямованих на підтримку культурних, наукових та освітніх проектів, сприяння молодіжним обмінам і надання стипендій за програмами мобільності. У 2012 р. бюджет фонду, складений із внесків урядів країн Вишеградської групи, дорівнював 7 мільйонам євро. Програми, які впроваджує даний фонд, здатні посилити співробітництво між нашою країною та країнами ЄС, на підставі вивчення позитивного досвіду та впровадження ефективних і налагоджених освітніх програм сумісно з закордонними колегами [2, с. 128].

Досить великою популярністю в Україні та інших країнах користуються програми Центру документації освіти в Європі (Documetation centre for education in Europe) та програми Ради з культурного співробітництва (Council for cultural cooperation), основним напрямком діяльності яких $\epsilon$ вирішення проблем, пов'язаних із взаємовизнанням документів про освіту у країнах Європейського континенту, з різноманіттям Європейських освітніх систем та проблемами, які виникають при підготовці молоді до вищої освіти та отримання професій, до світу праці і мобільності. 
В Україні попитом користуються основні проекти даних центрів - п'ять великих проектів зі шкільної освіти, чотири з організації вищої освіти та педагогічних досліджень: «Побудова університету завтрашнього дня: політика і практика вищої освіти в Європі», «Вища освіта для демократичного суспільства» та ін. Впроваджуються також й Міжнародні програми в галузі вищої освіти започатковані різноманітними структурами в тому числі й закордонними фондами: ERASMUS (обмін студентами різних країн), FORCE (продовжене навчання), PETRA (базове навчання ), COMMET (співробітництво між університетом і бізнесом), EUROTECHNET (сприяння професій, пов'язаних з технологічними інноваціями), PHARE (розвиток дистанційної освіти), LINGUA (мовна підготовка) [2, с. 128-129].

Різноманітні закордонні фонди, що працюють в Україні є благодійними організаціями, які надають допомогу у вигляді грантів. За твердженням фахівців гранти є найбільш поширеною формою фрінансування проектів донорськими організаціями. 3 точки зору періодичності проведення грантові програми поділяються на:

- $\quad$ разові конкурси - програми грантів, які проводяться благодійними фондами один раз (як правило, вони спрямовані на досягнення певних цілей і завдань);

- циклічні конкурси - програми грантів, які повторюються через певні проміжки часу - одиндва рази на рік;

- постійні конкурси - програми грантів, які не мають певних термінів подання заявок на фінансування. Проекти розглядаються за фрактом їх надходження [7, с. 5].

3 появу перших благодійних фондів в Україні громадські організації, освітні установи, наукові колективи, окремі дослідники змушені були опановувати технології фандрайзингу. Фандрайзинг це професійна діяльність щодо мобілізації фрінансових та інших ресурсів для реалізації соціально значущих і науково-дослідних неприбуткових проектів, яка вимагає спеціальних знань та навичок фандрайзера, що можуть вплинути на прийняття позитивного рішення донора [15, с. 12].

Отже, у зв'язку з недофінансуванням освіти та науки в Україні з боку держави ресурси закордонних фондів стали важливим джерелом втілення наукових й освітніх проектів. Фахівці зазначають, що за результатами досліджень Україна має високий рівень інтелектуального потенціалу, однак $є$ однією з не багатьох держав, де існує велика різниця між наявним інтелектуальним потенціалом та можливістю його повноцінної реалізації й перетворення у готовий продукт. Це спричинено складною економічною ситуацією в нашій країні, що є наслідком трансформаційних перетворень та кризових явищ останніх десятиліть, які спровокували скорочення видатків держави на науково-дослідні роботи, фінансування науки і освіти тощо. В реалізації творчих здібностей і знань науковців через забезпечення їх необхідними ресурсами для довгострокових і середньострокових проектів і програм можуть надати підтримку та допомогу вітчизняні і закордонні організації, фонди і установи. Тому актуальним на сьогодні є вміння знайти необхідні фронди, пробудити інтерес до свого проекту, презентувати його, чітко сорормулювати заявку, розробити програму заходів для залучення додаткових ресурсів на втілення програм, проектів та дослідних робіт $[15$, с. 10].

Висновки. Отже, в якості висновку можна стверджувати, що розбудовуючи національну систему освіти, українські державні діячі та науковці цілком справедливо орієнтувалися на кращі закордонні зразки. Але разом з тим не уникнули проблеми некритичного сприйняття європейських освітніх стандартів, поспішності в їх імплементації, визначення їх співмірності з національними педагогічними традиціями. У зв'язку з кризовими явищами в український економіці, хронічним недофінансуванням освіти та науки важливу роль у збереженні інтелектуального потенціалу нації відіграють зарубіжні фонди. Низка програм, що ними здійснюється в Україні сприяють міжнародній співпраці вітчизняних ВН3, забезпеченню академічної мобільності викладачів та студентів, реалізації освітньо-наукових проектів, виданню необхідної навчальної та наукової літератури.

\section{Література}

1. Білоцерківська, Н. Г. Політична складова соціокультурної компетентності молоді в умовах сучасного суспільства / Н. Г. Білоцерківська // Сучасне суспільство. - 2014. - Вип. 2. - С. 5-14.

2. Говоровська, О. Трансформація української освіти в контексті розвитку світових інформаційних технологій / О. Говоровська // Наукові записки з української історії. - 2015. - Вип. 37. - С. 124-130.

3. Діяльність Представництва Фонду Конрада Аденауера в Україні // Часопис Парламент. - 2003. - № 3-4. - С. 14.

4. Діяльність Фонду імені Фрідріха Еберта в Україні. - К. : Фонд імені Ф.Еберта, 1999. - 65 с. 
5. Єлдинова, І. М. Зміст освітньої благодійної діяльності фонду Олександра фон Гумбольдта / І. М. Єлдинова // Вісник ЛНУ імені Тараса Шевченка. - 2013. - № 3 (262). - С. 232-238.

6. Жихарєва, Т. Л. Діяльність німецьких політичних фондів в Україні (1992-2007рр.) / Т. Л. Жихарєва // Збірник наукових праць [Харківського національного педагогічного університету імені Г. С. Сковороди]. Серія : "Історія та географрія". - 2011. - Вип. 40. - С. 38-41.

7. Комаровський, О. В. Фандрейзинг у питаннях, відповідях та цитатах: навч. посіб. / О. В. Комаровський. - Луганськ, 2007. - 54 с.

8. Мозальов, В. Є. Моніторинг якості освіти: вітчизняний та зарубіжний досвід / В. Є. Мозальов // Вісник Національного університету оборони України. - 2014. - Вип. 5. - С. 99-104.

9. Національна академія педагогічних наук України [Електронний ресурс]. - Режим доступу: http://naps.gov.ua/ua/activities/international/grantmakers/.

10. Перспективи українсько-німецької регіональної співпраці в контексті розширення ЕС на схід. Зустріч з групою депутатів Ляндтаґу землі Шлезвіг-Голльштайн (Німеччина) // Незалежний культурологічний часопис «і». - 2001. - 6 липня.

11. Розвиток волонтерського руху через діяльність шкільних євроклубів України та Польщі. Підготовка до ЄВРО 2012. [Електронний ресурс] : Грант Міжнародного фонда "Відродження". Програма "Схід-Схід: Партнерство без кордонів" / Міжнародні проекти, що виконувалися в Україні. - Режим доступу: http://www.irf.ua/index.php?option=com content\&view =article\&id=36426\&ltemid=486.

12. Скотна, Н. Сутність глобалізації та її вплив на розвиток вищої освіти в Україні / Надія Скотна // Людинознавчі студії. Сер. : Філософрія. - 2012. - Вип. 26. - С. 71-83.

13. Українські освітяни ознайомилися 3 польськими молодіжними программами [Електронний ресурс] Програма "Схід-Схід: Партнерство без кордонів" / Міжнародні проекти, що виконувалися в Україні. - Режим доступу: http://www.irf.ua/index.php?option=com content\&view=article\&id=33594:2011-07-01-05-41-34\&catid=26:newseast\&ltemid=66.

14. Проект концепції розвитку освіти України на період 2015-2025 років [Електронний ресурс]. - Режим доступу: http://www.mon.gov.ua/ua/pr-viddil/1312/1390288033/1414672797/. - Назва з екрана.

15. Чернявська, О. В. Фандрайзинг. Навч. посіб. - 2-е вид., з доопрац. та допов. / О. В. Чернявська, А. М. Соколова. - К. : Алерта, 2015. - 272 с.

16. Якименко, О. О. Зміст і особливості трансформації вищої освіти в Україні / О. О. Якименко // Наукові праці [Чорноморського державного університету імені Петра Могили комплексу "Києво-Могилянська академія"]. Сер. : Державне управління. - 2012. - Т. 181, Вип. 169. - С. 41-44.

\section{References}

1. Bilotserkivska, N. H. (2014). Politychna skladova sotsiokulturnoi kompetentnosti molodi $v$ umovakh suchasnoho suspilstva [Political component of sociocultural competence of young people in the conditions of modern society]. Suchasne suspilstvo - Modern society, 2, 5-14 [in Ukrainian].

2. Hovorovska, O. (2015). Transformatsiia ukrainskoi osvity v konteksti rozvytku svitovykh informatsiinykh tekhnolohii [Transformation of Ukrainian Education in the Context of the Development of World Information Technologies]. Naukovi zapysky z ukrainskoi istorii - Scientific Notes on Ukrainian History, 37, 124-130 [in Ukrainian].

3. Diialnist Predstavnytstva Fondu Konrada Adenauera v Ukraini [Activities of the Representative Office of the Conrad Adenauer Foundation in Ukraine]. (2003). Chasopys Parlament - Bulletin Parliament, 3-4, 14 [in Ukrainian].

4. Diialnist Fondu imeni Fridrikha Eberta $v$ Ukraini [Activities of the Friedrich Ebert Foundation in Ukraine]. (1999). Kyiv: Fond imeni F. Eberta [in Ukrainian].

5. Yeldynova, I. M. (2013). Zmist osvitnoi blahodiinoi diialnosti fondu Oleksandra fon Humboldta [Contents of the educational charitable activity of the fund of Alexander von Humboldt]. Visnyk LNU imeni Tarasa Shevchenka - Bulletin of the Taras Shevchenko National University of Lviv, 3(262), 232-238 [in Ukrainian].

6. Zhykharieva, T. L. (2011). Diialnist nimetskykh politychnykh fondiv v Ukraini (1992-2007 rr.) [The activities of the German political foundations in Ukraine (1992-2007)]. Zbirnyk naukovykh prats [Kharkivskoho natsionalnoho pedahohichnoho universytetu imeni H. S. Skovorody]. Seriia : "Istoriia ta heohrafiia" - Collection of scientific works [Kharkiv National Pedagogical University named after G. S. Skovoroda]. Series: History and Geography, 40, 38-41 [in Ukrainian].

7. Komarovskyi, O. V. (2007). Fandreizynh u pytanniakh, vidpovidiakh ta tsytatakh [Fundraising in questions, answers and quotes]. Luhansk [in Ukrainian].

8. Mozalov, V. Ye. (2014). Monitorynh yakosti osvity: vitchyznianyi ta zarubizhnyi dosvid [Monitoring quality of education: domestic and foreign experience]. Visnyk Natsionalnoho universytetu oborony Ukrainy - Bulletin of the National Defense University of Ukraine, 5, 99-104 [in Ukrainian].

9. Mizhnarodni fondy ta orhanizatsii-hrantodavtsi [International foundations and organizations-grantors]. (n.d.). naps.gov.ua. Retrieved from http://naps.gov.ua/ua/activities/international/grantmakers/ [in Ukrainian].

10. Perspektyvy ukrainsko-nimetskoi rehionalnoi spivpratsi $v$ konteksti rozshyrennia ES na skhid. Zustrich z hrupoiu deputativ Liandtagu zemli Shlezvig-Hollshtain (Nimechchyna) 6 lypnia 2001 [Prospects of Ukrainian-German regional cooperation in the context of EU enlargement to the east. Meeting with the Landtag group of Land Schleswig-Holstein (Germany). July 6 2001]. (n.d.). www.ji-magazine./viv.ua. Retrieved from http://www.ji-magazine.lviv.ua/seminary/2001/sem0607.htm [in Ukrainian].

11. Rozvytok volonterskoho rukhu cherez diialnist shkilnykh yevroklubiv Ukrainy ta Polshchi. Pidhotovka do YeVRO 2012 : Hrant Mizhnarodnoho fonda "Vidrodzhennia". Prohrama "Skhid-Skhid: Partnerstvo bez kordoniv" [Development of the volunteer movement through the activities of school Euroclubs of Ukraine and Poland. Preparation for EURO 2012 : Grant of the International Renaissance Foundation. East-East: Partnership Beyond Borders]. (n.d.). www.irf.ua. Retrieved from http://www.irf.ua/index.php?option=com_content\&view=article\&id=36426\&ltemid=486 [in Ukrainian] . 
12. Skotna, N. (2012). Sutnist hlobalizatsii ta yii vplyv na rozvytok vyshchoi osvity $v$ Ukraini [The Essence of Globalization and its Impact on the Development of Higher Education in Ukraine]. Liudynoznavchi studii. Ser.: Filosofiia - Linguistics Studies. Series: Philosophy, 26, 71-83 [in Ukrainian].

13. Ukrainski osvitiany oznaiomylysia z polskymy molodizhnymy prohrammamy : Prohrama "Skhid-Skhid: Partnerstvo bez kordoniv" [Ukrainian educators got acquainted with Polish youth programs : East-East: Partnership without frontiers]. (n.d.). www.irf.ua. Retrieved from http://www.irf.ua/index.php?option=com_content\&view=article\&id=33594:2011-0701-05-41-34\&catid=26:newseast\& Itemid=66 [in Ukrainian]

14. Proekt kontseptsii rozvytku osvity Ukrainy na period 2015-2025 rokiv [Draft concept of the development of Ukrainian education for the period 2015-2025]. (n.d.). www.mon.gov.ua. Retrieved from http://www.mon.gov.ua/ua/prviddil/1312/1390288033/1414672797/ [in Ukrainian].

15. Cherniavska, O. V., Sokolova, A. M. (2015). Fandraizynh [Fundraising]. (2nd ed., rev.). Kyiv: Alerta [in Ukrainian].

16. Yakymenko, O. O. (2012). Zmist i osoblyvosti transformatsii vyshchoi osvity v Ukraini [Content and Peculiarities of the Transformation of Higher Education in Ukraine]. Naukovi pratsi [Chornomorskoho derzhavnoho universytetu imeni Petra Mohyly kompleksu "Kyievo-Mohylianska akademiia"]. Ser.: Derzhavne upravlinnia - Scientific Papers [Petro Mohyla Black Sea State University of Kyiv-Mohyla Academy Complex], 181, 169, 41-44 [in Ukrainian].

Надійшла 19.10 .2018

Бібліографічний опис для цитування :

Якимчук, О.І. Європейський вектор розвитку української освіти в період утвердження незалежності / О. І. Якимчук // Проблеми соціальної роботи: філософрія, психологія, соціологія. - 2018. - № 2 (12). - С. 88-95. 